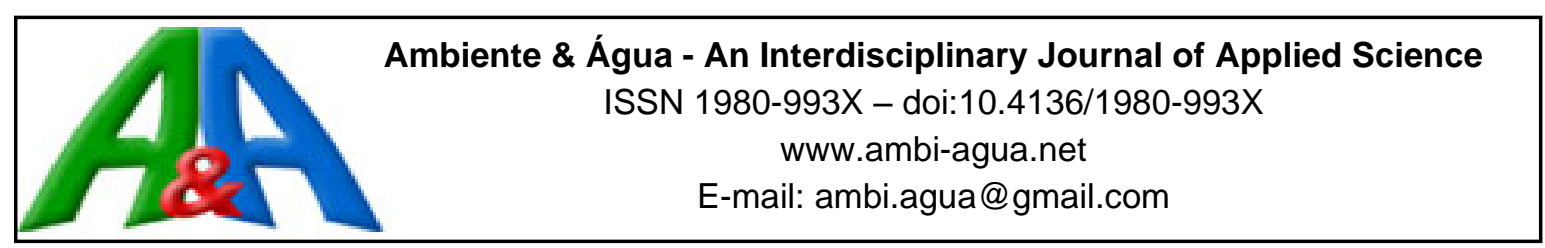

\title{
Ozonation as a pre-treatment of landfill leachate
}

\author{
ARTICLES doi:10.4136/ambi-agua.2592
}

Received: 08 Jun. 2020; Accepted: 15 Sep. 2020

\section{Leticia Tamara Hoffmann ${ }^{(D)}$ Matheus Caneles Batista Jorge* ${ }^{*}$; Adriana Garcia do Amaral ${ }^{\infty}$; Milene Carvalho Bongiovani ${ }^{\circledR}$; Roselene Maria Schneider}

\begin{abstract}
Instituto de Ciências Agrárias e Ambientais. Universidade Federal de Mato Grosso (UFMT), Avenida Alexandre Ferronato, n 1200, CEP: 78557-267, Sinop, MT, Brazil. E-mail: 1thhoffmann@gmail.com, adrianagamaral@gmail.com, milene.bongiovani@gmail.com,roselenems@yahoo.com.br

*Corresponding author. E-mail: jorge.batista2@ hotmail.com
\end{abstract}

\begin{abstract}
Ozone is an oxidizing agent with a potential for removing complex molecules, including those of difficult microbiological decomposition, such as the molecules found in landfill leachates. This effluent presents high organic content, including recalcitrant molecules. Therefore, this study evaluated the efficiency of ozonation in the treatment of raw leachate at the Primavera landfill, located in Mato Grosso, Brazil. The experiments were carried out using the batch system. The leachate $\mathrm{pH}$ value was set at 7 and 10, and the contact times between the gas and the leachate were 20,40,60, 80, and 100 minutes. Throughout the study, we analyzed color, turbidity, $\mathrm{pH}$ value, chemical oxygen demand (COD), and ultraviolet absorbance at 254 $\mathrm{nm}$ (UV abs) of the leachate, both before and after ozonation. Results show that ozonation presented high removal of color, $\mathrm{COD}$ and $\mathrm{UV}$ abs when $\mathrm{pH}$ was 7 . In contrast, turbidity removal was higher when the $\mathrm{pH}$ value was 10 . Regarding contact time, we observed a high removal of color (between $80 \%$ and $90 \%$ ) and UV abs (between $60 \%$ and $70 \%$ ) at 40 minutes, depending on the $\mathrm{pH}$ value. Removal was also high for turbidity (approximately $75 \%$ ) starting at 20 minutes with the $\mathrm{pH}$ value at 10 , and at 70 minutes with $\mathrm{pH}$ at 7 . The removal relation within all analyzed parameters (due to ozone consumption) decreased throughout the reaction time. Thus, we concluded that ozonation as a pre-treatment of leachate is indeed satisfactory because of its great capacity for organic material removal.
\end{abstract}

Keywords: degradation, leachate, ozone.

\section{Ozonização como pré-tratamento de lixiviado de aterro sanitário}

\section{RESUMO}

O ozônio é um agente oxidante com potencial para remoção de moléculas complexas, de difícil decomposição microbiológica, como as moléculas presentes em lixiviados. Este efluente apresenta alta carga orgânica, sendo parte desta recalcitrante. Assim, neste trabalho avaliou-se a eficiência da ozonização no tratamento do lixiviado bruto do aterro sanitário de Primavera, localizado no município de Sorriso - MT. Os experimentos foram realizados em batelada, com o valor de $\mathrm{pH}$ do lixiviado ajustado em 7 e 10, e tempos de contato entre o gás e o lixiviado iguais a 20, 40, 60, 80 e $100 \mathrm{~min}$. Foram analisados cor, turbidez, pH, DQO e absorbância ultravioleta a $254 \mathrm{~nm}$ (abs UV) do efluente antes e após a ozonização. Os resultados indicaram 
que a ozonização apresentou maiores remoções de cor, DQO e abs UV em pH 7, ao passo que a remoção de turbidez foi maior em pH 10. Em relação ao tempo de contato, foram observadas altas remoções de cor (entre 80 e $90 \%$ ) e abs UV (entre 60 e $70 \%$ ) em 40 minutos, dependendo do valor de $\mathrm{pH}$; e turbidez (aproximadamente 75\%) a partir do tempo 20 minutos, em valor de pH 10, e em 70 minutos, em pH 7. A relação de remoção entre todos os parâmetros analisados em função do consumo de ozônio foi decrescente ao longo do tempo de reação. Por fim, conclui-se que o emprego da ozonização como pré-tratamento de lixiviado é satisfatório, pois apresenta boa remoção de material orgânico.

Palavras-chave: chorume, degradação, ozônio.

\section{INTRODUCTION}

Population growth results in a disorderly growth of cities, mainly in large urban areas, which causes serious problems, especially in regard to the generation of urban waste and its final destination. Concern for residue disposal is studied both in a national (Agostinho et al., 2013) and an international scale (Lombardi et al., 2017), due to the awareness surrounding environmental protection.

The main worry regarding the release of residues is the liquids produced by the landfill, commonly known as leachate. Landfill leachate has high concentrations of organic matter, chlorides, ammoniacal nitrogen, as well as organic compounds of difficult degradation, such as humic substances and metals, depending on the properties of the residues disposed of in the landfill (Renou et al., 2008; Kawahigashi et al., 2014). If discarded inadequately, leachate can cause serious environmental harm.

When one considers efficient techniques for the decomposition of complex compounds, the ozonation technique stands out, either alone or associated with other processes (advanced oxidation processes/AOPs). Thus, it was the technique of choice in this study, and it appears to yield great results in the degradation of recalcitrant molecules (Araújo et al., 2016), as well as in the oxidation and mineralization of organic and inorganic species (Dezotti, 2008). The mentioned technique also showed high efficiency in the reduction of biochemical and chemical oxygen demands (BOD and COD, respectively) (Carvalho et al., 2018; Gomes and Schoenell, 2018; Brito and Silva, 2012) and turbidity (Mondardo et al., 2006).

The treatment process of landfill leachates through ozonation takes place by exposing the effluent to ozone gas. This gas is commonly generated by the Corona effect, which consists of passing atmospheric air between two electrodes. These two electrodes, due to their potential difference, will generate an electric discharge that breaks down the $\mathrm{O}_{2}$, resulting in the formation of atomic oxygen, which will bond to another $\mathrm{O}_{2}$ molecule and form ozone (Balakrishnan et al., 2002; Kunz et al., 1999; Almeida et al., 2004).

Ozone reacts with various organic compounds, chiefly amines and aromatic compounds rich in electrons, such as phenols and alkoxylated benzenes, which results in $\cdot \mathrm{OH}$ in parallel reactions. Therefore, $\bullet \mathrm{OH}$ is always formed when potable water and residual water are treated with ozone (von Sonntag and von Gunten, 2012).

Thereby, the key of the ozone treatment is based on the $\mathrm{O}_{3}$ direct reaction or on its indirect form, by generating the $\mathrm{OH}$ radical. Ozone, due to its elevated standard reduction potential $\left(\mathrm{E}^{0}\right.$ $=2.08 \mathrm{~V}$ ) reacts slowly and has high selectivity in regards to a great number of organic compounds (Almeida et al., 2004; Geppert, 2018). However, OH radicals also present a high standard reduction potential $\left(\mathrm{E}^{0}=2.80 \mathrm{~V}\right)$ and react quickly and without a selection for the majority of the compounds in an aqueous solution (Metcalf and Eddy, 2015; Li et al., 2018).

The most studied components that influence the ozonation treatment are ozone dosage (Jung et al., 2017), exposure time to the gas (Camilo Júnior et al., 2019), pH value (Buffle et 
al., 2006), effluent characteristics (Silva and Jardim, 2006; Xu et al., 2002), among others (Galdeano et al., 2018).

This paper therefore evaluated the reduction of the initial values of color, turbidity, chemical oxygen demand, UV abs and $\mathrm{pH}$ variance of the raw leachate sampled from a landfill in Sorriso, MT, by considering the influence of $\mathrm{pH}$ value and contact time with ozone.

\section{MATERIALS AND METHODS}

The raw leachate was sampled at a landfill in Primavera, in the city of Sorriso, Mato Grosso, Brazil. The facility has been in operation since 2011, and receives solid residues from Class IIA, which is non hazardous and non inert, and Class IIB, which is non hazardous and inert. It services more than twelve cities and processes twelve thousand tonnes of residue each month.

In order to treat landfill leachate, there is a system that combines biological and coagulation and flocculation processes (a waste stabilization pond and a physical-chemical treatment). Apart from being licensed by the regulating agencies in charge, the landfill possesses a system for monitoring physical and biotic factors.

The experiments were carried out in the Water and Wastewater Laboratory (LAR) at the Federal University of Mato Grosso (UFMT), in Sinop, Mato Grosso.

The elements that composed the ozonation system were an ozone generator; a bubble column reactor with a sparger on its base to defuse ozone into the landfill leachate; a series of three one-liter beakers, where the first one is responsible for reception and storage of the foam, an event that takes place in the reactor, and the other two are responsible for capturing the exceeding ozone (Figure 1). The seizing of ozone was accomplished by using a potassium iodide solution (KI), and its concentration was $20 \mathrm{~g} \mathrm{~L}^{-1}$. Silicone hoses were also used to connect the beakers.

The ozone generator deployed was the model that uses the Corona effect with atmospheric air, and its nominal production capacity was $0.4 \mathrm{~g} \mathrm{O}_{3} \mathrm{~h}^{-1}$.

The experimental tests were performed following the methodology cited by Guimarães et al. (2010).

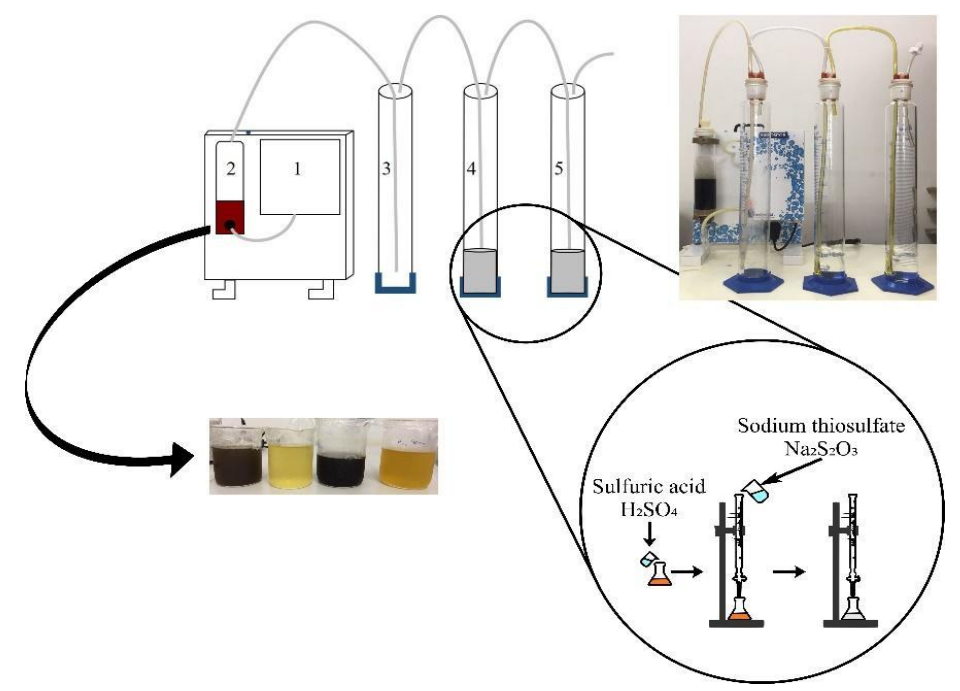

Figure 1. Flowchart of the landfill leachate treatment by ozone [an ozone generator (1); a bubble column reactor to defuse the gas into the leachate (2); a beaker to retain foam (3); and beakers to capture ozone (4 and 5) in a potassium iodide solution]. 
Samples of distilled water (reagent blank) or of landfill leachate had their $\mathrm{pH}$ values set at 7 (or adjusted to 7.3 for water) and 10 . Portions $(0.2 \mathrm{~L})$ of water or effluents were added into the reactor. We added $0.2 \mathrm{~L}$ of potassium iodide (KI), its concentration set at $20 \mathrm{~g} \mathrm{~L}-1$, into the beakers used to capture ozone. The reactor and beakers were then sealed, and the ozonation tests were initiated using the predetermined times of 20, 40, 60, 80 and 100 minutes

After each ozonation time, samples of water or landfill leachate were removed from the reactor, and, for the landfill leachate, we carried out the determination of $\mathrm{pH}$ value, color, turbidity, UV absorbance at $254 \mathrm{~nm}$ (UV abs), and chemical oxygen demand (COD). Afterwards, the values of $\mathrm{pH}$, color, turbidity, and UV abs were obtained using the following pieces of equipment: a $\mathrm{pH}$ meter, a colorimeter, a turbidimeter, and a spectrophotometer, respectively. COD was determined through the heated chemical digestion method.

Then, after the tests, the potassium iodide on the beakers was used to quantify the exceeding ozone (non reactive) through an iodometric titration.

The consumed ozone was determined by the difference between the residual gas contained in the distilled water (reagent blank) and in the effluent.

The characterization of the landfill leachate in regard to the initial parameters is informed in Table 3. We verified that the effluent showed high values of color, turbidity, COD and humic substances (expressed in terms of UV abs), which indicates that the landfill leachate is heavy in pollutants.

The experimental design was entirely random in a $2 \times 5$ factorial design, with two $\mathrm{pH}$ values and five exposure times, resulting in ten samples with three repetitions. The analysis of variance was used, and, when we identified significant effects, we employed Tuckey's test in relation to $\mathrm{pH}$ value, and regression testing in relation to contact time.

\section{RESULTS AND DISCUSSION}

The results from the statistical analysis have shown that there was a significant effect $(\mathrm{p} \leq 0.05)$ from the initial $\mathrm{pH}$ value over the $\mathrm{pH}$ and COD parameters. Also, the interaction among the treatments showed a significant effect $(p \leq 0.05)$ for the removal of UV abs, color and turbidity.

As for the $\mathrm{pH}$ at 7 , we observed an increase in the $\mathrm{pH}$ value from the beginning of the experiment to its end (a negative variation). When the initial $\mathrm{pH}$ was 7 , it is believed that a few intermediate decomposition reactions release $\mathrm{OH}^{-}$ions, which causes the $\mathrm{pH}$ to increase. For the $\mathrm{pH}$ at 10 , we observed a decrease in the $\mathrm{pH}$ value from the beginning of the experiment to its end (a positive variation) (Table 1), which, despite being low, indicates the consumption of $\mathrm{OH}^{-}$ions, probably due to its reaction with ozone chain reactions (von Gunten, 2003).

The average value for the COD parameter, as a function of the initial $\mathrm{pH}$ value (Table 1), showed that a higher removal rate was obtained when $\mathrm{pH}$ was 7 . In neutral $\mathrm{pH}$ values there is, basically, ozone reacting with organic matter. When the $\mathrm{pH}$ value is elevated, there is a tendency to create a hydroxyl radical (a higher standard reduction potential in relation to the molecular ozone), but there is also a tendency for its elimination (Buffle et al., 2006), reducing its availability for indirect reaction.

Table 1. Effect of the $\mathrm{pH}$ treatment regarding the variation of the parameters: $\mathrm{pH}$ value and COD.

\begin{tabular}{ccc}
\hline $\mathbf{p H}$ value & Variation of $\mathbf{p H}(\boldsymbol{\%})^{*}$ & COD removal $(\boldsymbol{\%})$ \\
\hline 7 & -14.5 & 31.9 \\
10 & 1.7 & 17.7 \\
\hline
\end{tabular}

* Negative values point out an addition in $\mathrm{pH}$ variation, and positive values point out a decrease in $\mathrm{pH}$ variation, from the beginning to the end of the experiment. 
For $\mathrm{pH}$ values lower than 7.5 , the decomposition via direct oxidation $\left(\mathrm{O}_{3}\right)$ is highly efficient. For $\mathrm{pH}$ values higher than 7.5, the presence of hydroxide ions initiates the decomposition of ozone in radicals, causing an increase in organic decomposition through indirect oxidation (Takashina et al., 2018; Usepa, 1999). However, for $\mathrm{pH}$ values higher than 9 , the ions found in it (normally bicarbonate and carbonate) act as scavengers of $\bullet \mathrm{OH}$, so they limit indirect oxidative action, reducing the oxidation process (Takeuchi et al., 1997).

Differently, as described by Jung et al. (2017) in their work evaluating saltwater ozonation, the increase of the sample's $\mathrm{pH}$ value ( 7 to 9 ) did not affect the decay of ozonation concentration, due to its quick reaction with bromide ions. The authors describe that the $\mathrm{pH}$ value alteration, however, changed the bromide species, which modified the reactions with ozone without changing its decomposition.

The removal behaviors of color, UV abs and turbidity (in addition to the interaction of $\mathrm{pH}$ value and exposure time) are presented in Figure 2. Higher color removals occurred for contact times above $40 \mathrm{~min}$, with a better tendency of removal for the effluent in $\mathrm{pH}$ value set at 7 (Figure 2A).
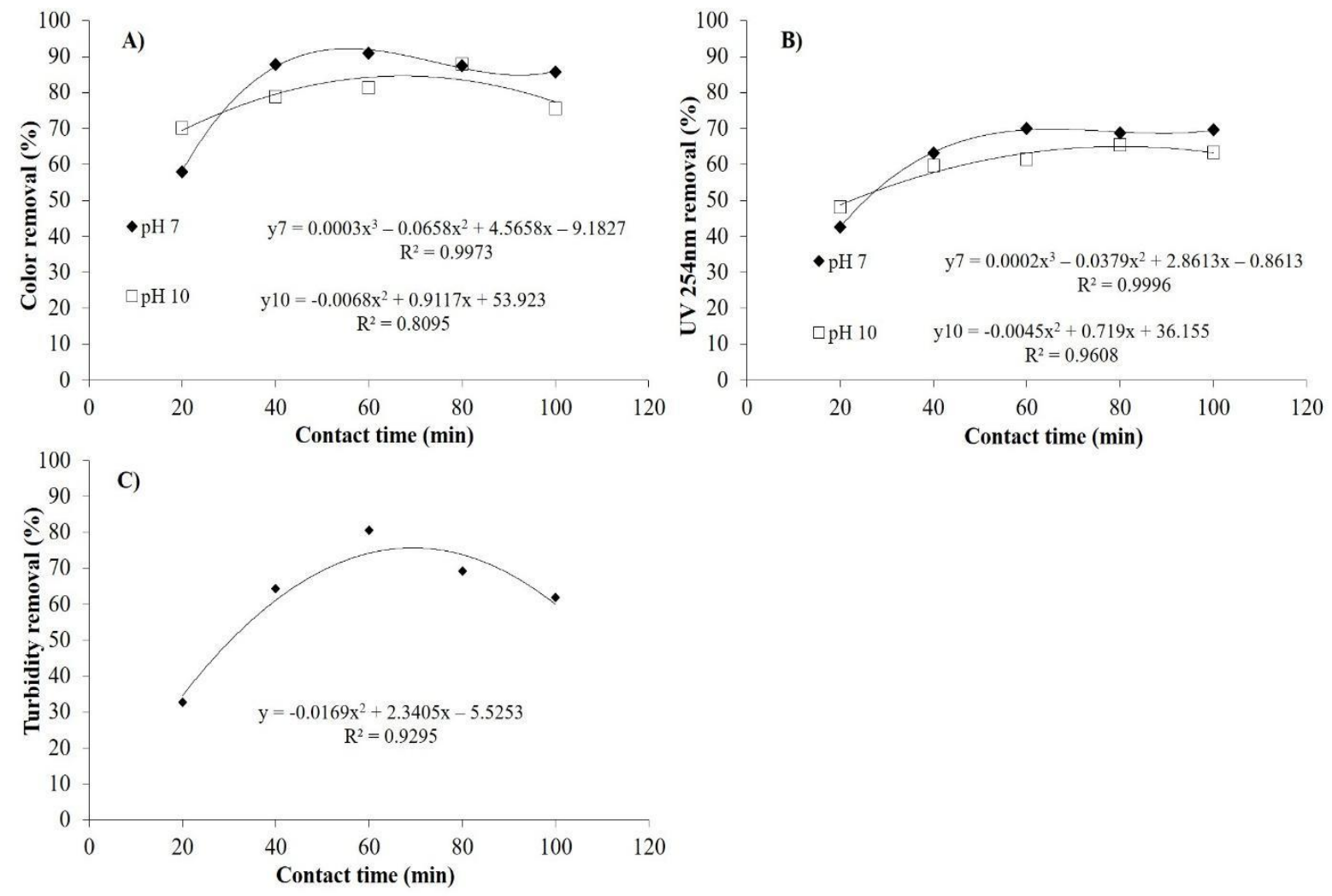

Figure 2. A) Effect of the contact time and the landfill leachate's initial $\mathrm{pH}$ value concerning color removal. B) Effect of the contact time and the leachate's initial $\mathrm{pH}$ value concerning $\mathrm{UV}_{254 \mathrm{~nm}}$ removal. C) Effect of the contact time and the leachate's initial $\mathrm{pH}$ value set at 7 concerning turbidity.

For the UV absorbance parameter, the results were the same as for color removal. However, this parameter showed lower average values of removal (see Figure 2B), which shows that there is a correlation between the parameters. The elements of colors and UV abs are linked to the presence of chromophoric substances in the liquid solution, thus removals or modifications in the chromophoric molecules cause interferences which can be noticed in the visible spectrum (color) and in ultraviolet (UV abs). See Figures 2A and 2B.

Due to the ozonation process applied to the leachate, the sample's initial dark color tends to present a light-yellow color. This reduction of color happens because of the ozone's or the 
$\mathrm{OH}$ radical's attack on the carbon double bond in the chromophore. The procedure results in the formation of the so-called "bleached" products, such as aliphatic acids, aldehydes, and ketones, which are by-products of low-molecular weight, normally biodegradable (Ntampou et al., 2006).

The ultraviolet radiation at $254 \mathrm{~nm}$ is easily absorbed by many organic, inorganic and colloidal compounds that integrate the effluents, which means it is associated with the presence of unsaturated and aromatic compounds (chromophores) in the liquid solution. Therefore, the reduction of UV abs, as well as color removal, is observed through the oxidation of such aromatic compounds (Cortez et al., 2010; Oloibiri et al., 2015).

Results have shown that, both for color (Figure 2A) and UV abs (Figure 2B), there is a tendency for higher removal rates when the timer is set for approximately 60 minutes when $\mathrm{pH}$ value is 7 , reaching removal rates higher than $90 \%$ and around $70 \%$ for color and UV abs, respectively. Regarding the $\mathrm{pH}$ values set at 10 , the tendency for a higher removal occurred at approximately around 70 and 80 minutes. We also observed average removals of $80 \%$ for color, and $60 \%$ for UV abs.

However, we observed that the removal rates for time spans shorter than 70-80 minutes are close to the values of maximum removal. In these cases, it becomes interesting to evaluate ozone production costs. It is necessary to observe production feasibility for longer periods of time, so the parameters can be reduced by $10 \%$.

Then we observed that color and UV abs removal have an increasing rate in the initial times, but, as it advances, the oxidation rate from the organic compounds becomes stable. This same behavior was noticed by Cortez et al. (2010) regarding COD and UV abs, resulting in the hypothesis that the molecular ozone might have reacted with the unsaturated and aromatic compounds, and thus generated compounds that have a slower reaction and which are resistant to complementary oxidation, such as aliphatic acids and aldehydes.

These compounds produced by oxidation do not absorb the ultraviolet spectrum. However, they contribute to COD, which explains the higher removal of absorbance regarding the chemical oxygen demand. Moreover, the landfill leachate's high quantity of organic compounds (Table 3) limits COD removal, as well as possible concentrations of inorganic carbon, which are responsible for consuming $\mathrm{OH}$ radicals, therefore restricting the system's efficiency (Oloibiri et al., 2015).

As for turbidity (Figure 2C), the maximum removal occurred, approximately, at $70 \mathrm{~min}$ $(75 \%)$ for the $\mathrm{pH}$ at 7 . However, we observed that after 40 minutes removals exceeded $60 \%$. Therefore, continuing the ozonation until it reaches 70 minutes may not be a viable alternative. As was suggested for the color and UV abs parameters, it is valid to consider the costs of ozone production.

The turbidity removal when $\mathrm{pH}$ was at 10 did not present any significant regression models ( $\mathrm{p} \leq 0.05$ ), reaching an average removal of around $74 \%$.

The tendency of reduction for turbidity removal (according to the contact time) can have a correlation with precipitating metals, such as iron and manganese; although they were not quantified, these metals were probably part of the composition of the landfill leachate used in the study. The formation of precipitating particles was observed, mainly in higher ozonation times. The precipitated particles stood at the bottom of the reactor. At the end of the ozonation time, the precipitated particles were collected with the samples, which gave the samples turbidity (see Figure 2C).

Iron and manganese are soluble in their lower oxidation states $\left(\mathrm{Fe}^{+2} \mathrm{e} \mathrm{Mn}^{+2}\right)$, but they are relatively insoluble at their higher oxidation states $\left(\mathrm{Fe}^{+3} \mathrm{e} \mathrm{Mn}{ }^{+4}\right)$. This is why these cations can precipitate in the forms of iron hydroxide and manganese hydroxide (Apha et al., 1998).

According to von Gunten (2003), the main oxidation for these inorganic compounds is via direct oxidation, using molecular ozone. As a result, it is possible that a partial oxidation of 
these elements via molecular $\mathrm{O}_{3}$ happened. In addition, the precipitates formed are easily removed using sedimentation and filtration processes after ozonation (Moruzzi and Reali, 2012).

\subsection{Ozone consumption}

The relation of color, turbidity, UV abs, and COD removal, in function of ozone consumption, has shown significant changes $(\mathrm{p} \leq 0.05)$ regarding the isolated treatments, but no significant changes were detected regarding the interaction between them. The variation of $\mathrm{pH}$ value did not show any significant change for the evaluated variables either.

As for color, UV abs, and COD, the highest relation of removal due to ozone mass took place when $\mathrm{pH}$ was 7 , independent of contact time. For turbidity, the highest removal occurred when $\mathrm{pH}$ was set at 10 (Table 2).

Table 2. Effect of the leachate's initial $\mathrm{pH}$ value regarding the removal of the parameters analyzed by milligram of ozone consumed.

\begin{tabular}{|c|c|c|c|c|}
\hline pH value & 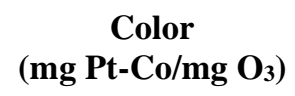 & $\begin{array}{c}\text { UV abs } \\
\left(\mathbf{a b s} / \mathrm{mg} \mathrm{O}_{3}\right)\end{array}$ & 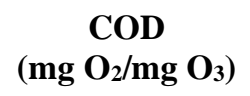 & Turbidity (NTU/mg $\mathrm{O}_{3}$ ) \\
\hline 7 & 39.333 & 0.028 & 4.817 & 2.133 \\
\hline 10 & 23.933 & 0.018 & 1.819 & 4.000 \\
\hline
\end{tabular}

Considering the contact time regarding the removal of the parameters analyzed (Figure 3), we observed that the highest ozone mass removals consumed for the parameters color, turbidity, UV abs, and COD took place in the shorter reaction times. This behavior reflects the highest concentration of the elements in the beginning of the treatment, which favors their contact with the oxidizing agent. As the contact time increases, the concentration of the parameters reduces and, consequently, there is less use of the ozone that enters the system (Cortez et al., 2011; Zhang et al., 2018).

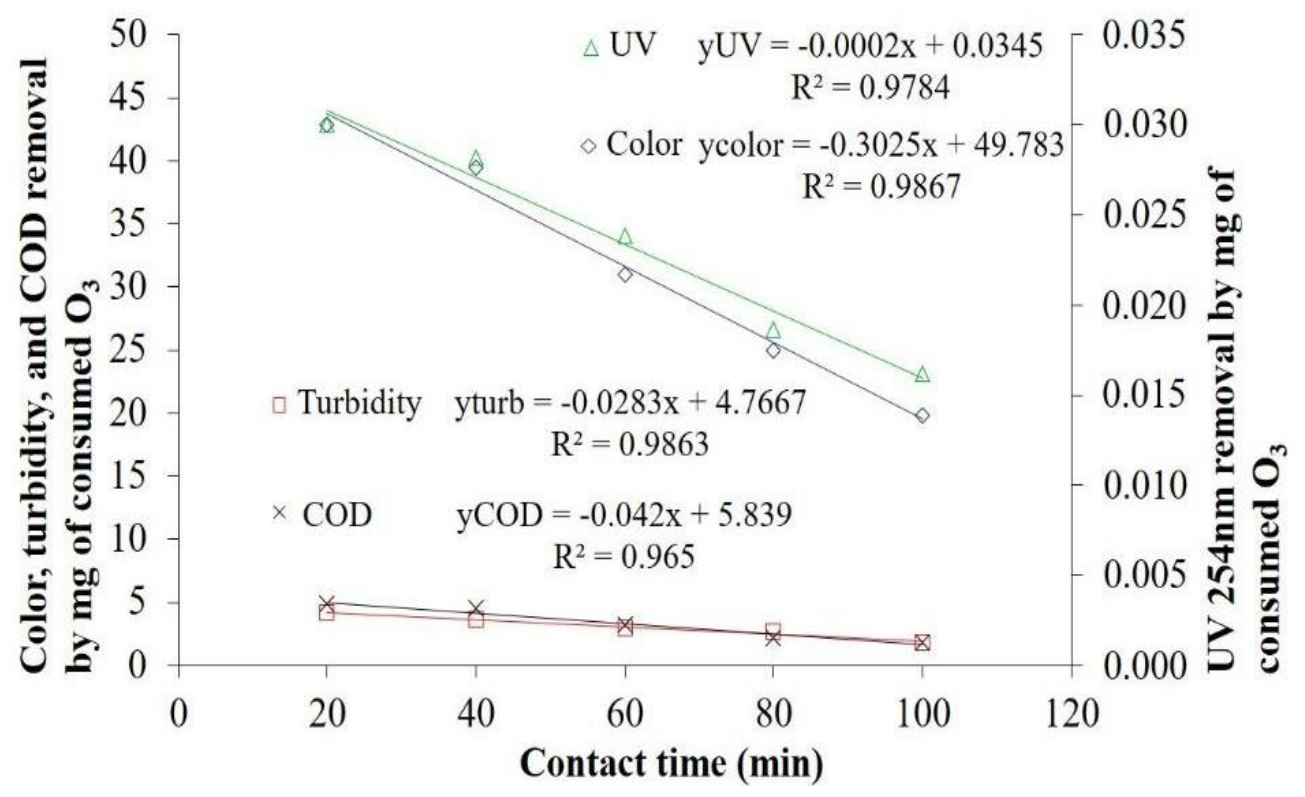

Figure 3. Effect of contact time concerning color, turbidity, UV abs, and COD removals by milligram of ozone consumed. 
The residual values of color, turbidity, UV abs, and COD, determined after the treatment (Table 3), show that the landfill leachate presented high values regarding the parameters analyzed.

Table 3. Residual values obtained for the parameters of raw and treated landfill leachate analyzed, in addition to contact time and initial $\mathrm{pH}$ value.

\begin{tabular}{|c|c|c|c|c|}
\hline \multirow{2}{*}{ Parameters } & \multicolumn{2}{|c|}{ pH 7} & \multicolumn{2}{|c|}{ pH 10} \\
\hline & Raw effluent & Treated effluent & Raw effluent & Treated effluent \\
\hline \multicolumn{5}{|c|}{$20 \mathrm{~min}$} \\
\hline Color (mg Pt-Co L L-1) & 14940.00 & 6215.00 & 11870.00 & 3512.00 \\
\hline Turbidity (NTU) & 1104.00 & 743.00 & 1981.00 & 610.00 \\
\hline $\mathrm{pH}$ value & 7.44 & 8.30 & 9.83 & 9.73 \\
\hline $\mathrm{UV}_{254 \mathrm{~nm}}(\mathrm{abs})$ & 13.94 & 7.99 & 12.35 & 6.40 \\
\hline $\operatorname{COD}\left(\mathrm{mg} \mathrm{O}_{2} \mathrm{~L}^{-1}\right)$ & 4321.00 & 3194.00 & 4158.00 & 3393.00 \\
\hline \multicolumn{5}{|c|}{$40 \mathrm{~min}$} \\
\hline Color (mg Pt-Co L'-1) & 15020.00 & 1845.00 & 13570.00 & 2858.00 \\
\hline Turbidity (NTU) & 1104.00 & 400.00 & 2618.00 & 770.00 \\
\hline $\mathrm{pH}$ value & 7.35 & 8.51 & 9.79 & 9.70 \\
\hline $\mathrm{UV}_{254 \mathrm{~nm}}(\mathrm{abs})$ & 14.25 & 5.23 & 13.48 & 5.45 \\
\hline $\operatorname{COD}\left(\mathrm{mg} \mathrm{O}_{2} \mathrm{~L}^{-1}\right)$ & 4318.00 & 2497.00 & 4045.00 & 3381.00 \\
\hline \multicolumn{5}{|c|}{$60 \mathrm{~min}$} \\
\hline Color (mg Pt-Co L L-1) & 15100.00 & 1346.00 & 13140.00 & 2478.00 \\
\hline Turbidity (NTU) & 1104.00 & 248.00 & 2700.00 & 788.00 \\
\hline $\mathrm{pH}$ value & 7.54 & 8.60 & 9.82 & 9.67 \\
\hline $\mathrm{UV}_{254 \mathrm{~nm}}(\mathrm{abs})$ & 14.66 & 4.37 & 13.36 & 5.17 \\
\hline $\operatorname{COD}\left(\mathrm{mg} \mathrm{O}_{2} \mathrm{~L}^{-1}\right)$ & 4335.00 & 2700.00 & 4042.00 & 3384.00 \\
\hline \multicolumn{5}{|c|}{$80 \mathrm{~min}$} \\
\hline Color (mg Pt-Co L L-1) & 14826.00 & 1836.00 & 11880.00 & 1427.00 \\
\hline Turbidity (NTU) & 1104.00 & 366.00 & 2177.00 & 262.00 \\
\hline $\mathrm{pH}$ value & 7.52 & 8.65 & 9.82 & 9.61 \\
\hline $\mathrm{UV}_{254 \mathrm{~nm}}(\mathrm{abs})$ & 13.78 & 4.29 & 12.44 & 4.30 \\
\hline $\mathrm{COD}\left(\mathrm{mg} \mathrm{O}_{2} \mathrm{~L}^{-1}\right)$ & 4691.00 & 3406.00 & 3868.00 & 3122.00 \\
\hline \multicolumn{5}{|c|}{$100 \mathrm{~min}$} \\
\hline Color (mg Pt-Co L L & 14826.00 & 2060.00 & 10890.00 & 2656.00 \\
\hline Turbidity (NTU) & 1104.00 & 408.00 & 2188.00 & 840.00 \\
\hline $\mathrm{pH}$ value & 7.52 & 8.72 & 9.86 & 9.57 \\
\hline $\mathrm{UV}_{254 \mathrm{~nm}}(\mathrm{abs})$ & 13.78 & 4.19 & 11.95 & 4.38 \\
\hline $\mathrm{COD}\left(\mathrm{mg} \mathrm{O}_{2} \mathrm{~L}^{-1}\right)$ & 4691.00 & 3609.00 & 4370.00 & 3531.00 \\
\hline
\end{tabular}

Thus, we identified that the values for color, COD and UV abs of the raw effluent were distinct among the $\mathrm{pH}$ values. Those with lower values of $\mathrm{pH}$ showed the highest values in the parameters. As for the turbidity values, we also observed some difference; however, the highest values were for the $\mathrm{pH}$ set at 10. Aziz et al. (2007) investigated the effect of the $\mathrm{pH}$ value regarding color reaction in the landfill leachate's treatment process; they also verified that its 
black color became light-brown, as the effluent's $\mathrm{pH}$ value was reduced or increased, due to the chemical precipitation of humic substances. Therefore, the simple act of increasing or reducing the landfill leachate's $\mathrm{pH}$ value may have promoted a removal of the parameters analyzed.

It is important to highlight that, although the values obtained after the ozonation are high, the treatment did promote a significant reduction of the parameters studied, which can improve or reduce the landfill leachate's post-treatment time.

The ozone integration using other oxidation processes, such as electrochemical and chemical processes (Araújo et al., 2016), are alternatives to achieving the values established by the norm. Also, another interesting alternative is the association between the gas and adsorption processes. Poblete et al. (2017) observed good color and COD removals by using ozone and activated charcoal.

Bila et al. (2004) have shown that the sequence of coagulation-flocculation treatments + ozonation + biological treatment increases the efficiency of the biological treatment stage. Silva and Daniel (2015), by using ozone followed by chlorine disinfection, obtained good removals of biochemical oxygen demand.

\section{CONCLUSION}

Throughout the study, regarding the leachate's hydrogen ionic potential, we observed higher color, COD and UV abs removals when we used $\mathrm{pH}$ value at 7; and, for turbidity, when we set $\mathrm{pH}$ to 10 .

When considering contact time, we verified that, in an exposure of 40 minutes, a good removal for color, turbidity and UV absorbance $\left(\mathrm{UV}_{254 \mathrm{~nm}}\right)$ takes place.

The relation of removal due to ozone consumption decreases as the contact time increases.

Even though the ozonation process has presented good percentages of removal for the parameters analyzed, it must not be applied as the only stage of treatment, since it was not possible to achieve the quality required by the legislation for releasing it into bodies of water. Therefore, it is fundamental to associate it to the methodology of other treatments.

Some alternatives, such as varying the concentration of gas and associating the advanced oxidation processes (AOP) with other advanced or conventional processes, can be interesting from the point of view that it would be a reduction in the effluent load, which would make its treatment less complex.

\section{ACKNOWLEDGEMENTS}

The authors would like to thank the Institute of Agricultural and Environmental Sciences, Federal University of Mato Grosso (UFMT-Sinop), for the financial support.

\section{REFERENCES}

AGOSTINHO, F.; ALMEIDA, C. M. V. B.; BONILlA, S. H.; SACOMANO, J. B.; GIANNETTI, B. F. Urban solid waste plant treatment in Brazil: Is there a net energy yield on the recovered materials? Resources, Conservation and Recycling, v. 73, p. 143-155, 2013. https://doi.org/10.1016/j.resconrec.2013.02.001

ALMEIDA, E.; ASSALIN, M. R.; ROSA, M. A.; DURÁN, N. Tratamento de efluentes industriais por processos oxidativos na presença de Ozônio. Química Nova, v. 27, n. 5, p. 818-824, 2004. http://doi.org/10.1590/S010040422004000500023

APHA; AWWA; WEF. Standard Methods for the Examination of Water and Wastewater. 20. ed. Washington, 1998. 
ARAÚJO, K. S.; ANTONELLI, R.; GAYDECZKA, B.; GRANATO, A. C.; MALPASS, G. R. P. Processos oxidativos avançados: uma revisão de fundamentos e aplicações no tratamento de águas residuais urbanas e efluentes industriais. Revista Ambiente \& Água, v. 11, n. 2, p. 387-401, 2016. https://doi.org/10.4136/ambi-agua.1862

AZIZ, H. A.; ALIAS, S.; ADLAN, M. N.; FARIDAH, A. A. H. ZAHARI, M. N. Colour removal from landfill leachate by coagulation and flocculation processes. Bioresource Technology, v. 98, n. 1, p. 218-220, 2007. https://doi.org/10.1016/j.biortech.2005.11.013

BALAKRISHNAN, P. A.; ARUNAGIRI, A.; RAO, P. G. Ozone generation by silent electric discharge and its application in tertiary treatment of tannery effluent. Journal of Electrostatics, v. 56, n. 1, p. 77-86, 2002. https://doi.org/10.1016/S03043886(02)000311

BILA, D. M.; MONTALVÃO, A. F.; SILVA, A. C.; DEZOTTI, M. Ozonation of a landfill leachate: evaluation of toxicity removal and biodegradability improvement. Journal of Hazardous Materials, v. 117, n. 2-3, p. 235-242, 2004. https://doi.org/10.1016/j.jhazmat.2004.09.022

BRITO, N. N.; SILVA, V. B. M. Processo oxidativo avançado e sua aplicação ambiental. Revista Eletrônica de Engenharia Civil, v. 1, n. 3, p. 36-47, 2012. https://dx.doi.org/10.5216/reec.v3i1.17000

BUFFLE, M.; SCHUMACHER, J.; MEYLAN, S.; JEKEL, M.; VON GUNTEN, U. Ozonation and Advanced Oxidation of Wastewater: Effect of $\mathrm{O}_{3}$ Dose, $\mathrm{pH}$, DOM and HOScavengers on Ozone Decomposition and HO- Generation. Ozone: Science and Engineering, v. 28, n. 4, p. 247-259, 2006. https://doi.org/10.1080/01919510600718825

CAMILO JÚNIOR, O. B.; SANDRI, D.; ALENCAR, E. R.; HEBLING, L. F. Ozonation improves physical attributes in domestic sewage effluent. Revista Ambiente \& Água, v. 14, n. 2, 2019. https://doi.org/10.4136/ambi-agua.2328

CARVALHO, M. C. S.; BORGES, A. C.; PEREIRA, S. P.; HELENO, F. F.; FARONI, L. R. A.; CAMPOS, L. C. Combined use of $\mathrm{O} 3 / \mathrm{H} 2 \mathrm{O} 2$ and $\mathrm{O} 3 / \mathrm{Mn} 2+$ in flotation of dairy wastewater. Revista Ambiente \& Água, v. 13, n. 2, 2018. https://dx.doi.org/10.4136/1980-993X

CORTEZ, S.; TEIXEIRA, P.; OLIVEIRA, R.; MOTA, M. Evaluation of Fenton and ozonebased advanced oxidation processes as mature landfill leachate pre-treatments. Journal Hazardous Materials, v. 92, n. 3, p. 749-755, 2011. https://doi.org/10.1016/j.jenvman.2010.10.035

CORTEZ, S.; TEIXEIRA, P.; OLIVEIRA, R.; MOTA, M. Ozonation as polishing treatment of mature landfill leachate. Hazardous Materials, v. 182, p. 730-734, 2010. https://doi.org/10.1016/j.jhazmat.2010.06.095

DEZOTTI, M. (Coord.). Processos e técnicas para o controle ambiental de efluentes líquidos. Rio de Janeiro: E-papers, 2008. 360p.

GALDEANO, M. C.; WILHELM, A. E.; GOULART, I. B.; TONON, R. V.; FREITAS-SILVA, O.; GERMANI, R.; CHÁVEZ, D. W. H. Effect of water temperature and pH on the concentration and time of ozone saturation. Brazilian Journal of Food Technology, v. 21, 2018. http://dx.doi.org/10.1590/1981-6723.15617 
GEPPERT, M. Avaliação da eficiência de degradação de azo corante amido black 10B em solução aquosa por ozônio. 2018, 221f. Dissertação (Mestrado em avaliação de impactos ambientais) - Universidade La Salle, Canoas, 2018.

GOMES, P. L.; SCHOENELL, E. K. Aplicação de ozônio e ozônio + peróxido de hidrogênio para remoção de compostos recalcitrantes em lixiviados de aterros sanitários. Engenharia Sanitária e Ambiental, v. 15, n. 1, p. 93-98, 2018. https://doi.org/10.1590/s1413-41522018155758

GUIMARÃES, J. R.; ALMEIDA JÚNIOR, R. L.; MANIERO, M. G.; FADINI, P. S. Ozonização em meio básico para redução de cor do licor negro de indústria de celulose de algodão. Engenharia Sanitária e Ambiental, v. 15, n, 1, p. 93-98, 2010. https://doi.org/10.1590/S1413-41522010000100011

JUNG, Y.; HONG, E.; KWON, M.; KANG, J. A kinetic study of ozone decay and bromine formation in saltwater ozonation: Effect of $\mathrm{O} 3$ dose, salinity, $\mathrm{pH}$, and temperature.

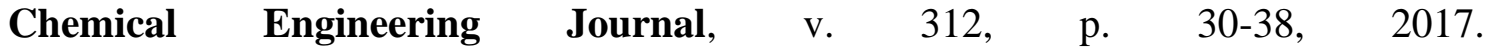
https://doi.org/10.1016/j.cej.2016.11.113

KAWAHIGASHI, F.; MENDES, M. B.; ASSUNÇÃO JÚNIOR, V. G.; GOMES, V. H.; FERNANDES, F.; HIROOKA, E. Y.; KURODA, E. K. Pós-tratamento de lixiviado de aterro sanitário com carvão ativado. Engenharia Sanitária e Ambiental, v. 19, n. 3, p. 236-244, 2014. https://doi.org/10.1590/S1413-41522014019000000652

KUNZ, A.; FREIRE, R. S.; ROHWEDDER, J. J. R.; DURAN, N. Construção e otimização de um sistema para produção e aplicação de ozônio em escala de laboratório. Química Nova, v. 22 , n. 3, p. 425-428, 1999. http://doi.org/10.1590/S0100-40421999000300022

LI, X.; CHEN, W.; MA, L.; WANG, H.; FAN, J. Industrial wastewater advanced treatment via catalytic ozonation with an Fe-based catalyst. Chemosphere, v. 195, p. 336-343, 2018. https://doi.org/10.1016/j.chemosphere.2017.12.080

LOMBARDI, F.; COSTA, G.; SIRINI, P. Analysis of the role of the sanitary landfill in waste management strategies based upon a review of lab leaching tests and new tools to evaluate leachate production. Revista Ambiente \& Água, v. 12, n. 4, p. 543-555, 2017. http://dx.doi.org/10.4136/ambi-agua.2096

METCALF, L.; EDDY, H. P. Tratamento de efluentes e recuperação de recursos. Tradução de Ivanildo Hespanhol e José Carlos Mierzwa. 5. ed. Porto Alegre: McGraw Hill; Bookman, 2015. 2008 p.

MONDARDO, R. I.; SENS, M. L.; MELO FILHO, L. C. Pré-tratamento com cloro e ozônio para remoção de cianobactérias. Engenharia Sanitária e Ambiental, v. 11, n. 4, p. 337 342, 2006. http://doi.org/10.1590/S141341522006000400006

MORUZZI, R. B.; REALI, M. A. P. Oxidação e remoção de ferro e manganês em águas para fins de abastecimento público ou industrial - uma abordagem geral. Revista de Engenharia e Tecnologia, v. 4, n. 1, p. 29-43, 2012.

NTAMPOU, X.; ZOUBOULIS, A. I.; SAMARAS, P. Appropriate combination of physicchemical methods (coagulation/flocculation and ozonation) for the efficient treatment of landfill leachates. Chemosphere, v. 62, n. 5, p. 722-730, 2006. https://doi.org/10.1016/j.chemosphere.2005.04.067 
OLOIBIRI, V.; UFOMBA, I.; CHYS, M.; AUDENAERT, W. T. M.; DEMEESTERE, K.; VAN HULLE, S. W. H. A comparative study on the efficiency of ozonation and coagulation-flocculation as pretreatment to activated carbon adsorption of biologically stabilized landfill leachate. Waste Management, v. 43, p. 335-342, 2015. https://doi.org/10.1016/j.wasman.2015.06.014

POBLETE, R.; OLLER, I.; MALDONADO, M. L.; LUNA, Y.; CORTES, E. Cost estimation of COD and color removal from landfill leachate using combined coffee-waste based activated carbon with advanced oxidation processes. Journal of Environmental $\begin{array}{llllllll}\text { Chemical Engineering, } & \text { v. 5, n. } & \text { 1, } & \text { p. } & \text { 114-121, }\end{array}$ https://doi.org/10.1016/j.jece.2016.11.023

RENOU, S.; GIVAUDAN, J. G.; POULAIN, S.; DIRASSOUYAN, F.; MOULIN, P. Landfill leachate treatment: Review and opportunity. Journal of Hazardous Materials, v. 150, n. 3, p. 468-493, 2008. https://doi.org/10.1016/j.jhazmat.2007.09.077

SILVA, G. H. R.; DANIEL, L. A. Desinfecção de efluente anaeróbio com o uso de ozônio/cloro. Engenharia Sanitária e Ambiental, v. 20, n. 2, p. 279-288, 2015. https://doi.org/10.1590/S1413-41522015020000083662

SILVA, L. M.; JARDIM, W. F. Trends and strategies of ozone application in environmental problems. Química Nova, v. 29, n. 2, p. 310-317, 2006. https://doi.org/10.1590/S010040422006000200023

TAKASHINA, T. A.; LEIFELD, V.; ZELINSKI, D. W.; MAFRA, M. R.; IGARASHIMAFRA, LUCIANA. Application of Response Surface Methodology for Coffee Effluent Treatment by Ozone and Combined Ozone/UV. Ozone: Science \& Engineering, v. 40, n. 4, p. 293-304, 2018. https://doi.org/10.1080/01919512.2017.1417112

TAKEUCHI, Y.; MOCHIDZUKI, K.; MATSUNOBU N.; KOJIMA, R.; MOTOHASHI, H.; YOSHIMOTO, S. Removal of organic substances from water by ozone treatment followed by biological activated carbon treatment. Water Science and Technology, v. 35, n. 7, p. 171- 178, 1997. https://doi.org/10.1016/S0273-1223(97)00128-5

USEPA. Alternative disinfectants and oxidants: guidance manual. Washington, 1999. 328 p.

VON GUNTEN, U. Ozonation of drinking water: Part I. Oxidation kinetics and product formation. Water Research, v. 37, n. 7, p. 1443-1467, 2003. https://doi.org/10.1016/S0043-1354(02)00457-8

VON SONNTAG, C.; VON GUNTEN, U. Chemistry of ozone in water and wastewater treatment from basic principles to applications. Londres: IWA Publishing, 2012. 302 p.

XU, P.; JANEX, M. L.; SAVOYE, P.; COCKX, A.; LAZAROVA, V. Wastewater disinfection by ozone: main parameters for process design. Water Research, v. 36, p. 1043-1055, 2002. https://doi.org/10.1016/S0043-1354(01)00298-6

ZHANG, J.; HUANG, G.; LIU, C.; ZHANG, R.; CHEN, X.; ZHANG, L. Synergistic effect of microbubbles and activated carbon on the ozonation treatment of synthetic dyeing wastewater. Separation and Purification Technology, v. 201, p. 10-18, 2018. https://doi.org/10.1016/J.SEPPUR.2018.02.003 